\title{
Gene-exposure interaction in occupational and environmental epidemiology: Results from an ongoing study
}

\author{
Elin H. Kure, Marit Thorsen and Inger-Lise Hansteen \\ Department of Occupational and Environmental Medicine, Telemark Central Hospital, Skien, Norway \\ Correspondence to: Elin H. Kure, Department of Occupational and Environmental Medicine, Section of Genetics, \\ Telemark Central Hospital, N-3710 Skien, Norway \\ Telephone: +4735003500 Telefax: +4735003105 e-mail: elin.kure@tss.telemax.no
}

\begin{abstract}
A tissue bank is established in our department on a total of 659 persons whereof 341 are included in the Nordic data base on somatic chromosome damage in humans. Genotyping of susceptibility genes relevant to the exposures of the cohort is an ongoing undertaking in our laboratory. GST's and $m E H$ have been genotyped for 80 persons so far, $C Y P^{\prime}$ s for 20 persons. When the mean number of chromatide breaks and of cells with aberrations were related to genotypes no statistical difference could be observed between the genotypes for either parameter. No difference in cytogenetic damage between exposed and referents or between smokers and non-smokers were identified for the two separate occupational studies these 80 persons represent. The results of the various cytogenetic endpoints were trichotomized and compared to the genotype distribution. Although not statistically significant, the observed trend with higher percentage of persons with polymorphic GST $\square 1$ in particular, but also for GST $\square 1$ and $m E H$ (exon 4) in the group with high frequency of chromosome aberrations will be interesting to follow. For further follow-up studies, a nested case-control study within the cohort would give a more rapid and less expensive approach than analysing each study separately as a traditional case-control study. As high frequency of chromosomal damage is associated with cancer development, the hypothesis to be tested would be whether genetic polymorphisms for the most appropriate susceptibility genes could be an explanatory factor for this association.
\end{abstract}

\section{INTRODUCTION}

Whether a chemical contributes to cancer or other diseases depends not only on the extent of an individual's exposure, but also on the effectiveness of the body's defence response. These responses are known to vary from one individual to another, sometimes profound$1 y^{1}$. Chemical and physical agents can induce cancer through various mechanisms that alter the expression or function of either proto-oncogenes or tumour suppressor genes. Variability also exists in the capacity to repair DNA damage, and potential polymorphisms in repair genes may also be a risk factor ${ }^{1,2}$.

Some genes are disease determining genes and not dependent upon exposure to exert an effect. Another class of genes, which is the focus of this paper, is dependent upon exposure to exert an effect. These genes are called modifying genes in genetic terminology, and susceptibility genes in molecular epidemiology. Some of these genes may have slight variations in the coding sequences, they are polymorphic. If the same variant (allele) is inherited from both parents, the individual is homozygote for this polymorphic gene, while a combination of alleles leads to heterozygosity. Variations in genes are referred to as genetic polymorphisms only if it exists in the population in at least two phenotypes, neither of which occurs at a frequency of less than $1 \%{ }^{3}$. The susceptibility genes alter risk, but are neither necessary nor sufficient for disease causation. Unlike the disease determining genes, the prevalence of susceptibility genes is often high in a population and the role of environmental exposure is crucial. They may impart relatively small risk, but since the frequencies are so high, the attributable risks can be high ${ }^{4}$.

The relationship between genetic polymorphisms of biotransformation enzymes and the risk of disease is currently a rapidly increasing field of knowledge. There is a growing number of different genetic polymorphisms which are being evaluated for their potential influence on health. For many enzymes, the genetic basis of the functional variability is still not well understood and the only choice is phenotyping (i.e., CYP1A2). However, for some enzymes the variability is almost completely explained and correctly predicted by genotype (i.e., GST $\square 1$, GST $\square 1$ and NAT2).

Genotyping assays, based on polymerase chain reaction (PCR), are highly reliable and robust and in many cases fairly easy to perform. However, unknown 
gene variants may escape detection and thus functionally important variants are not taken into account. Genotyping in molecular epidemiology is only feasible if there is a limited number of mutant alleles of the gene in the population under study.

Although an essential feature of susceptibility genes is that there should be an exposure to a compound that is metabolised by the particular enzyme being studied, not all studies have included exposure assessments. In these studies the focus has been on the distribution of gene variants between cases and controls. As enzymes are related to specific exposures, it is important to know about the metabolic pathway for determining which susceptibility genes it is relevant to test for in an occupational setting, and further which biomarker it is relevant to evaluate.

As measures of exposure and effect, a number of biomarkers have been developed, such as structural aberrations in chromosomes (CA), micronuclei (MN), aneuploidy, sister chromatide exchanges (SCE) and adducts (an adduct is created when a chemical interacts with either DNA or other biological molecules) ${ }^{5-8}$. These biomarkers are mainly used as effect biomarkers. However, they may also serve as dosimeters for exposure to genotoxic compounds and reflect interindividual variability in metabolism ${ }^{9,10}$. The choice of biomarker is dependent on the chemical(s) in question. There is a notion that increased quantities of biomarkers could reflect added liability for cancer.

In this paper we want to focus on the most relevant susceptibility genes in occupational epidemiology that are relevant for risk assessment. These genes and the most relevant chemicals metabolised by the enzymes they code for are described in more detail in the Appendix. The use of cytochrome $P 450$ (CYP), glutatione S-transferase (GST), and microsomal epoxide hydrolase $(m E H)$ will be exemplified by preliminary results from our laboratory relating genotyping to cytogenetic biomarkers as indicator of exposure. This will demonstrate the pitfalls, underline the necessity of epidemiological design and good exposure characterisation.

\section{MATERIALS AND METHODS}

\section{Study population and study design}

A tissue bank is established in our department on a total of 659 persons whereof 341 are included in the Nordic data base on somatic chromosome damage in humans ${ }^{11,12}$. All persons have participated in casecontrol studies monitoring occupational exposure with cytogenetic damage as effect parameters. The Nordic cohort is included in the European Study Group on Cytogenetic Biomarkers and Health. In the Nordic study and later in the European study high frequencies of chromosomal aberrations (CA) were identified as a possible genetic marker of cancer risk independent of gender, age at test, or times since tested ${ }^{13}$.
To identify high frequencies of CA the various cytogenetic endpoints were trichotomized on the basis of the absolute value distribution within each participating laboratory as "low" (1-33 percentile), "medium" (34-66 percentile) or "high" (67-100 percentile). For our laboratory the actual figures for number of cells with aberrations were $\leq 1.0 \%, 1.0 \%-2.0 \%,>2.0 \%$ for the three groups, respectively. A study relating relevant susceptibility genes to the frequency of CA in this cohort is underway. Preliminary results are presented in a case-control design ${ }^{14}$.

One group of the study population consisted of 10 maintenance workers in an ethylene plant, all males. Even though the documented exposures in the plant were below $1 \mathrm{ppm}$ for benzen and for 1,3-butadiene for many years, the study was undertaken due to expressed worry of possible high peak exposures among maintenance workers. Other chemicals of exposure were ethylene oxide, propylene oxide, C4-mix, toluene, styrene, olefines, dicyclopentadiene and white spirit. Exposure characterisations were based on group interviews with the participants, and on measurements performed on other workers during the relevant time periods. Individual exposure measurements were not available. Controls were 10 maintenance workers from the chloralkali production plant, not exposed to the listed chemicals, matched for gender, age and smoking. There were only two never-smokers in each group. The mean age was 49 years for both groups. For further details see reference 15 . The selection of susceptibility genes were based on knowledge about human metabolism of the chemicals defining the exposure of the work force (i.e., including tobacco smoke, see Appendix).

The other group comprised 31 oil exposed male workers from a cable manufacturing company and male office workers of the same age and smoking habits as controls, mean age 36 years, and with 13 and 14 non-smokers in each group, respectively. The exposure under study was naphthenic oils of low (2-6 $\mathrm{mm}^{2} / \mathrm{s}$ at $\left.40{ }^{\circ} \mathrm{C}\right)$ and high $\left(300-600 \mathrm{~mm}^{2} / \mathrm{s}\right.$ at $\left.40{ }^{\circ} \mathrm{C}\right)$ viscosity. Exposure measurements were performed at the work sites at the time of study. For detailed description of this group see reference 16. The selection of susceptibility genes were based on knowledge about human metabolism of the chemicals defining the exposure of the work force (i.e., including tobacco smoke, see Appendix).

All workers were exposed through inhalation and skin contamination.

\section{Methods}

Cytogenetic damage was studied according to conventional methods (i.e. $48 \mathrm{hr}$ lymphocyte cultures counting 200 cells per person) ${ }^{17}$.

DNA for genotyping of the maintenance workers were extracted from whole blood ${ }^{18}$ and from fixed cell 
suspensions for the cable workers (pers. comm. A. Hirvonen).

Susceptibility genes studied so far, are GST $\square 1$, $G S T \square 1, G S T \square 1, m E H$ (exons 3 and 4) for both groups and CYP1A1 (m1 and $\mathrm{m} 2)$; CYP2E1 (RsaI and DraI) for the maintenance group. For description of the methods see references 19-22.

Data analysis were performed in SPSS Base 8.0.

\section{RESULTS}

No difference in cytogenetic damage between exposed workers and controls or between smokers and nonsmokers were identified for the two groups studied ${ }^{15,16}$. The groups were pooled and the genotype distribution of the polymorphisms for the 80 persons, and for exposed and controls separately, is shown in Table 1 together with the expected frequencies of the genetic polymorphisms in Caucasian populations ${ }^{19,23-27}$. The distribution was similar for the two studied groups viewed separately, and did not differ from the expected frequencies. For $C Y P 1 A 1$ and $C Y P 2 E 1$ the studied group was small and no persons homozygote for the polymorphism were observed. The wild type is predominant in the Caucasian population. Although the frequencies are known to be low, we still think it is of interest to genotype for these genes when done in combination with individual biomarkers of effect and exposure.

To test if the most susceptible individuals might show an increase in cytogenetic damage even if exposures were low, the mean number of chromatide breaks and of cells with aberrations were related to genotype as shown in Table 2. No statistical difference could be observed between the genotypes for either parameter.

Table 1. Genotype distributions for $G S T \square 1, G S T \square 1, G S T \square 1, m E H$ exon 3 and $m E H$ exon 4 for the joint study group, and the $C Y P$ genotypes for the maintenance workers.

\begin{tabular}{|c|c|c|c|c|c|c|c|}
\hline & \multicolumn{2}{|c|}{ Exposed } & \multicolumn{2}{|c|}{ Controls } & \multicolumn{2}{|c|}{ Total } & \multirow{2}{*}{$\begin{array}{c}\text { Expected } \\
\%\end{array}$} \\
\hline & $\mathrm{n}$ & $\%$ & $\mathrm{n}$ & $\%$ & $\mathrm{n}$ & $\%$ & \\
\hline GST $\square 1$ - $^{\mathrm{a}}$ & 22 & 55.0 & 24 & 60.0 & 46 & 57.5 & $40-60$ \\
\hline GST $\square 1+^{\mathrm{b}}$ & 18 & 45.0 & 16 & 40.0 & 34 & 42.5 & $40-60$ \\
\hline GST $\square 1$ - & 7 & 17.5 & 9 & 22.5 & 16 & 20.2 & $10-30$ \\
\hline GST $\square 1+$ & 33 & 82.5 & 31 & 77.5 & 64 & 80.0 & $70-90$ \\
\hline GST $\square 1 \mathrm{wt}^{\mathrm{c}}$ & 19 & 47.5 & 22 & 55.0 & 41 & 51.3 & 52 \\
\hline GST $\square 1 \mathrm{hz}^{\mathrm{d}}$ & 18 & 45.0 & 15 & 37.5 & 33 & 41.3 & 31 \\
\hline GST $\square 1$ pm $^{\mathrm{e}}$ & 3 & 7.5 & 3 & 7.5 & 6 & 7.5 & 9 \\
\hline mEH exon $3 \mathrm{wt}$ & 22 & 52.5 & 14 & 35.0 & 35 & 43.8 & 36 \\
\hline mEH exon $3 \mathrm{hz}$ & 9 & 22.5 & 17 & 42.5 & 26 & 32.5 & 56 \\
\hline $\mathrm{mEH}$ exon $3 \mathrm{pm}$ & 10 & 25.0 & 9 & 22.5 & 19 & 23.8 & 8 \\
\hline mEH exon 4 wt & 29 & 72.5 & 30 & 75.0 & 59 & 73.8 & 59 \\
\hline mEH exon $4 \mathrm{hz}$ & 9 & 22.5 & 9 & 22.5 & 18 & 22.5 & 37 \\
\hline mEH exon 4 pm & 2 & 5.0 & 1 & 2.5 & 3 & 3.8 & 5 \\
\hline CYP1A1 m1 wt & 8 & 80.0 & 9 & 90.0 & 17 & 85.0 & $88-94$ \\
\hline CYP1A1 m1 hz & 2 & 20.0 & 1 & 10.0 & 3 & 3.0 & \\
\hline CYP1A1 m1pm & 0 & 0 & 0 & 0 & 0 & 0 & \\
\hline CYP1A1 m2 wt & 9 & 90.0 & 10 & 100.0 & 19 & 95.0 & 94 \\
\hline CYP1A1 m2 hz & 1 & 10.0 & 0 & 0 & 1 & 5.0 & \\
\hline CYP1A1 m2pm & 0 & 0 & 0 & 0 & 0 & 0 & \\
\hline CYP2E1 $1 \mathrm{wt}$ & 10 & 100.0 & 10 & 100.0 & 20 & 100.0 & 96 \\
\hline CYP2E1 $1{ }^{\mathrm{f}} \mathrm{hz}$ & 0 & 0 & 0 & 0 & 0 & 0 & \\
\hline CYP2E1 $1{ }^{\mathrm{f}} \mathrm{pm}$ & 0 & 0 & 0 & 0 & 0 & 0 & \\
\hline CYP2E1 $2 \mathrm{wt}$ & 7 & 70.0 & 8 & 80.0 & 15 & 75.0 & 90 \\
\hline CYP2E1 $2^{\mathrm{g}} \mathrm{hz}$ & 3 & 30.0 & 2 & 20.0 & 5 & 25.0 & \\
\hline CYP2E1 $2^{\mathrm{g}} \mathrm{pm}$ & 0 & 0 & 0 & 0 & 0 & 0 & \\
\hline
\end{tabular}

a) - $=0 / 0$ genotype b) $+=0 / 1$ or $1 / 1$ genotype c) $\mathrm{wt}=$ wildtype, homozygote d) $\mathrm{hz}=$ heterozygote, wildtype/polymorphism e) $\mathrm{pm}=$ polymorphism, homozygote 
Table 2. Distribution of cytogenetic damage for the different genotypes for the joint study group.

\begin{tabular}{|c|c|c|c|}
\hline Genotype & $\mathrm{n}$ & $\begin{array}{c}\text { Chromatide breaks } \\
(200 \text { cells) } \\
\text { Mean (SD) }\end{array}$ & $\begin{array}{l}\text { Cells with aberra- } \\
\text { tions }(100 \text { cells) } \\
\text { Mean (SD) }\end{array}$ \\
\hline 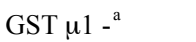 & 46 & $1.6(1.8)$ & $1.5(1.2)$ \\
\hline $\operatorname{GST} \square 1+{ }^{\mathrm{b}}$ & 34 & $1.6(1.7)$ & $1.5(1.4)$ \\
\hline GST $\square 1$ - & 16 & $1.6(2.0)$ & $1.5(1.6)$ \\
\hline GST $\square 1+$ & 64 & $1.6(1.7)$ & $1.5(1.2)$ \\
\hline GST $\square 1 \mathrm{wt}^{\mathrm{c}}$ & 41 & $1.5(1.6)$ & $1.3(1.3)$ \\
\hline GST $\square 1 \mathrm{hz}^{\mathrm{d}}$ & 33 & $1.7(1.9)$ & $1.8(1.4)$ \\
\hline GST $\square 1 \mathrm{pm}^{\mathrm{e}}$ & 6 & $1.8(2.2)$ & $1.4(1.1)$ \\
\hline $\mathrm{mEH}$ exon $3 \mathrm{wt}$ & 35 & $1.6(1.7)$ & $1.6(1.3)$ \\
\hline $\mathrm{mEH}$ exon $3 \mathrm{hz}$ & 26 & $1.4(1.4)$ & $1.1(0.7)$ \\
\hline $\mathrm{mEH}$ exon $3 \mathrm{pm}$ & 19 & $1.8(2.2)$ & $1.9(1.8)$ \\
\hline $\mathrm{mEH}$ exon $4 \mathrm{wt}$ & 59 & $1.6(1.7)$ & $1.5(1.1)$ \\
\hline $\mathrm{mEH}$ exon $4 \mathrm{hz}$ & 18 & $1.5(2.0)$ & $1.4(1.6)$ \\
\hline $\mathrm{mEH}$ exon $4 \mathrm{pm}$ & 3 & $2.3(1.2)$ & $3.0(2.2)$ \\
\hline
\end{tabular}

a) $-=0 / 0$ genotype b) $+=0 / 1$ or $1 / 1$ genotype c) $\mathrm{wt}=$ wildtype, homozygote d) $\mathrm{hz}=$ heterozygote, wildtype/polymorphism e) $\mathrm{pm}=$ polymorphism, homozygote

As a high frequency of CA has been shown to be associated with cancer development ${ }^{13}$, the results of the cytogenetic endpoints were trichotomized on the basis of the absolute value distribution as "low", "medium" or "high". The genotype distribution was compared between the "high" and "low/medium" groups of cells with CA (Table 3) to test if a higher number of susceptible individuals would be allocated to the high frequency group.

The groups were small and no statistical differences could be detected. A trend with higher percentage of persons in the polymorphic groups for GST $\square 1$ in particular, but also for $G S T \square 1$ and $m E H$ exon 4 in the group with high frequency of $\mathrm{CA}$ will be interesting to follow when the present study progresses.

A statistical evaluation of interactions between genes was not performed because of the small sample size. Of the 15 persons in the high CA frequency group, $13.3 \%(\mathrm{n}=2)$ had the triple gene combination GST $\square 1$-, GST $\square 1$-, GST $\square 1 \mathrm{hz} / \mathrm{pm}$ compared to $4.6 \%$ $(\mathrm{n}=3)$ in the low/medium group. In the high group $33.3 \%(\mathrm{n}=5)$ had the combination GST $\square 1-$, GST $\square 1+$, GST $\square 1 \mathrm{hz} / \mathrm{pm}$ compared to $23.1 \%(\mathrm{n}=15)$ in the low/medium group.

Comparing the various $G S T$ 's with $\mathrm{mEH}$ exon 3 and exon 4 separately, only $G S T \square 1$ and $m E H$ exon 4 combinations showed some interesting, consistent results using these small numbers. The gene combination GST $\square 1 \mathrm{wt}, m E H$ exon $4 \mathrm{wt}$ was found in $13.3 \%$ $(\mathrm{n}=2)$ in the high CA group, and in $40 \%(\mathrm{n}=26)$ in the low/medium group. The combination GST $\square 1 \mathrm{wt}, m E H$ exon $4 \mathrm{hz} / \mathrm{pm}$ was found in $33.3 \%(\mathrm{n}=3)$ and in $15.4 \%$ $(\mathrm{n}=10))$ in the high and low/medium groups, respectively. The combination $G S T \square \mathrm{l} \mathrm{hz/pm,} m E H$ exon 4 wt was found in $53.3 \%(\mathrm{n}=8)$ and $35.4 \%(\mathrm{n}=23)$ in the high and low/medium groups, while the combination $G S T \square 1 \mathrm{hz} / \mathrm{pm}, m E H$ exon $4 \mathrm{hz} / \mathrm{pm}$ was found in $13.3 \%$ $(\mathrm{n}=2)$ and in $9.2 \%(\mathrm{n}=6)$ in the high and low/medium groups, respectively.

Table 3. Level of cytogenetic damage related to genotype in the joint study group.

\begin{tabular}{|c|c|c|c|c|c|c|}
\hline \multirow[b]{2}{*}{ Genotype } & \multirow[b]{2}{*}{ Total } & \multicolumn{2}{|c|}{ Low/medium } & \multicolumn{2}{|c|}{ High } & \multirow[b]{2}{*}{$\square^{2}$} \\
\hline & & $\mathrm{n}$ & $\%$ & $\mathrm{n}$ & $\%$ & \\
\hline GST $\square 1-^{a}$ & 46 & 37 & 56.9 & 9 & 60.0 & \\
\hline GST $\square 1+^{b}$ & 34 & 28 & 43.1 & 6 & 40.0 & $\mathrm{p}=0.83$ \\
\hline GST \1 - & 16 & 12 & 18.5 & 4 & 26.7 & \\
\hline GST $\square 1+$ & 64 & 53 & 81.5 & 11 & 73.3 & $\mathrm{p}=0.47$ \\
\hline GST $\square 1 \mathrm{wt}^{\mathrm{c}}$ & 41 & 36 & 55.4 & 5 & 33.3 & \\
\hline GST $\square 1 \mathrm{hz} / \mathrm{pm}^{\mathrm{e}}$ & 39 & 29 & 44.6 & 10 & 66.7 & $\mathrm{p}=0.12$ \\
\hline $\mathrm{mEH}$ exon $3 \mathrm{wt}$ & 35 & 28 & 43.1 & 7 & 46.7 & \\
\hline $\mathrm{mEH}$ exon $3 \mathrm{hz} / \mathrm{pm}$ & 45 & 37 & 56.9 & 8 & 53.3 & $\mathrm{p}=0.79$ \\
\hline mEH exon $4 \mathrm{wt}$ & 59 & 49 & 75.4 & 10 & 66.7 & \\
\hline $\mathrm{mEH}$ exon $4 \mathrm{hz} / \mathrm{pm}$ & 21 & 16 & 24.6 & 5 & 33.3 & $\mathrm{p}=0.49$ \\
\hline
\end{tabular}

a) $-=0 / 0$ genotype b) $+=0 / 1$ or $1 / 1$ genotype c) $w t=$ wildtype, homozygote

d) $\mathrm{hz}=$ heterozygote, wildtype/polymorphism e) $\mathrm{pm}=$ polymorphism, homozygote 


\section{DISCUSSION}

Exposure assessment was not performed as individual measurements in either of the two groups studied. Measurements were performed at the work site giving an overall impression of the amount of exposure, and individual and group interviews gave a good overview of the chemicals used and the working tasks performed. In this way a good qualitative exposure characterisation could be assured, but quantitative assessment was lacking. Persons more exposed than others could be grouped, but individual differences in exposure were not evaluated and the variation could be great. Knowledge about the chemicals is necessary in order to determine which susceptibility genes it would be important to test for, but potential effect of the gene differences are dependent upon the level of exposure as well. The maintenance group was exposed to chemicals known to give cytogenetic damage ${ }^{5,28}$, but no effect of the present exposure could be detected. The study of the second group was undertaken in order to explore if exposure to oil mist would give cytogenetic damage. No effect of exposure was observed in this study either. The first prerequisite, exposure, was not present in high enough levels to be detected by the effect parameter used in the study. The question arose if an effect of exposure could be detected in susceptible individuals. Even if the susceptibility genes studied are relevant to the chemicals of exposure, which they are in the present study (see Appendix), another important factor is the frequency distribution of the gene in the general population. As seen from Table 1, the gene frequency distribution in occupational settings is in accordance with frequencies observed in the general population $^{19,23-27}$, as also found for other occupational settings ${ }^{29}$. If the polymorphic gene frequency is low, as it is for $C Y P$, even if the gene under study is highly relevant to the exposure, it would require a study population much larger than is available in most occupational settings to detect an effect. One would assume that this would be dependent on the quality of the exposure-dose-effect data as well.

In Table 2, two of the cytogenetic endpoints were correlated to genetic polymorphism in GSTs and $m E H$ (exons 3 and 4 ) in the combined group. No significant differences between the genotypes were seen indicating that no possible effect of exposure or life-style parameters could be detected in this way either in the present study. An association between GST $\square$ 1genotype and increased frequency of chromosome aberrations in smokers has been reported ${ }^{30}$.

Only a few studies are available on genetic polymorphism and cytogenetic damage in humans due to chemical exposures using in vivo and in vitro approaches. Thus far the studies have mainly addressed changes in SCE frequency associated with polymorphisms in GST $\square 1, G S T \square 1, C Y P 1 A 1, C Y P 2 D 6$ and $N A T 2$ for certain exposures such as smoking, diesel exhaust or 1,3-butadiene production workers (for review see Norrpa ${ }^{31}$ ). Some studies suggest that the genotype can have an influence on induced or baseline levels of cytogenetic damage ${ }^{32}$. However, in many of the studies performed also including cancer as the effect parameter ${ }^{33}$, conflicting results have been obtained. This is possibly due to the size of the effect being detected, the sample size, variation in the study population and the lack of studying interaction between relevant genes. Even if the present results on gene combinations is not tested statistically due to the sample size, the importance of gene combinations are indicated.

Results of the studies of the Nordic and European study groups suggest that the frequency of chromosomal damage in peripheral blood lymphocytes is a relevant biomarker for cancer risk in humans, reflecting either early biological effects of genotoxic carcinogens or individual cancer susceptibility ${ }^{12,13}$. If we

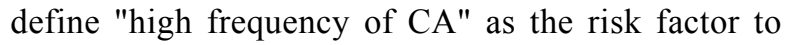
select for, in our combined study group independent of knowledge about occupational and environmental exposure levels, and combine this high frequency with susceptibility genotypes, a trend with higher percentage of persons with the polymorphic GST $\square 1$ genotype was observed even if it was not statistically significant due to the small groups studied (Table 3).

As presented in the results, despite low numbers of cases in each group, there is a consistent trend of higher frequencies of assumed high risk polymorphisms for the GST's and $m E H$ in the high CA group compared to the low/medium group. This trend will be of interest to further explore when the study progresses.

Assessment of risks to human health due to chemicals at the workplace or in the environment is the ultimate goal of environmental health sciences. The applicability of epidemiological studies is often limited because humans are exposed to low doses, often mixtures of chemicals and the studies reveal results only after a relatively large number of individuals have developed disease. Genetic markers may be used in epidemiological studies to increase the information obtained from classical study designs. If the gene-exposure interaction is looked upon as the genetic control of sensitivity to exposure, and genetic factors are regarded as one of the host characteristics, the gene-exposure interaction can be analysed through the use of traditional epidemiology study designs, as cohort, cross-sectional and case-control studies ${ }^{14}$. However, as demonstrated by these preliminary results and by the many conflicting results published so far, the complexity of using susceptibility markers in molecular epidemiology is greater than previously being addressed.

When designing such studies, it is important to have a clear hypothesis of the "exposure-dosedamage" relationship. Genetic markers should be chosen because of their biological relevance to the question addressed. Knowledge of biological significance of susceptibility genes, their interaction, their rele- 
vance to exposure and genetic markers of exposure/ damage is crucial to a good study design, as well as statistical power to detect an effect (which depends upon sample size and gene frequencies in the general population).

For further follow-up studies within the existing cohort in our laboratory, these preliminary results suggest that a nested case-control study within the cohort would possibly give a more rapid and less expensive approach, where cases are defined as all persons with high frequency of chromosome aberrations and controls are chosen among the rest of the cohort. As high frequency of chromosomal damage is associated with cancer development, the hypothesis to be tested would be whether genetic polymorphisms for the most appropriate susceptibility genes could be an explanatory factor for this association.

\section{ACKNOWLEDGEMENTS}

The skilful technical assistance in cyto- and molecular genetics performed by Kjell O. Klausen og Vera Haugan is greatly acknowledged together with the work done by the occupational hygienist Saskia Wanders.

\section{APPENDIX}

\section{CYP}

The cytochrome P450 enzymes generally make a wide range of chemicals less damaging, although they may sometimes generate reactive products capable of damaging DNA and other cellular components. Most chemical carcinogens require metabolic activation by cytochrome P450 for conversion to highly reactive electrophiles that bind covalently to DNA (i.e., phase I reactions) ${ }^{34-36}$. A number of genetic polymorphisms have been established for several isoenzymes of the P450 enzyme system (i.e., CYP2D6, CYP1A1, CYP2E1, CYP2A6, CYP2C9, CYP2C19, and CYP2C18 genes). These enzymes may play an important role in the metabolism and toxicity of chemicals, and functional polymorphisms in the genes may result in large interindividual variations in toxicity and cancer risk. The P450 isoenzymes of CYP1A1, CYP2A6, and CYP2E1 are involved in the metabolism of many potentially genotoxic compounds.

A problem in studying the $C Y P 1 A 1$ and $C Y P 2 E 1$ genetic polymorphisms is the relatively low occurrence of the mutant alleles, especially in Caucasian populations. This is a problem in molecular epidemiological studies since large groups of individuals are required in order to detect statistically significant effects.

\section{CYP1A1}

Many of the CYP1A1 substrates are carcinogens or are metabolised to carcinogens by the action of CYP1A1. The P450IA1 dependent enzyme aryl hydrocarbon hydroxylase (AHH), metabolises aromatic hydrocarbons such as polycyclic aromatic hydrocarbons (PAH). Four different polymorphisms are known in this gene which together with the wild type allele give rise to a number of various genotype frequencies in different populations ${ }^{21}$.

\section{CYP2E1}

CYP2E1 catalyses both oxidation and reduction reactions for a large number of low molecular weight substrates. Several of the substrates are carcinogens or are metabolised to carcinogens. Among the substrates are aromatic compounds (i.e., aniline, benzene, phenol, styrene, toluene, pyridine) and alcohols, aldehydes, ketons, nitriles, alkanes, alkenes (i.e., chloroform, hexane, vinyl chloride), and nitrosamines and azo compounds. The two most well studied polymorphisms are referred to as the RsaI/PstI and the DraI. There are a few others polymorphisms that are less studied ${ }^{37}$.

\section{CYP2A6}

$C Y P 2 A 6$ is involved in the metabolism of several carcinogenic compounds, such as aflatoxin B1, N-nitrosodiethylamine, and NNK. CYP2A6 also catalyses the hydroxylation of coumarin and plays a role in the metabolism of nicotine. Two polymorphisms are known in this gene $\mathrm{e}^{38}$.

\section{CYP2D6, CYP2C19 and CYP2C9}

The enzymes encoded by these genes, metabolises a number of important clinically used drugs. Several mutant forms of CYP2D6 have been detected in humans. The enzyme of CYP2D6 is involved in nicotine metabolism by activation of nitrosamines. CYP2C9 is the main enzyme involved in the metabolism of S-warfarin. CYP2C19 and CYP2C9 both have a couple of known polymorphisms ${ }^{38}$.

\section{GST}

Certain classes of detoxifying enzymes are in general more beneficial than the cytochrome P450 family in detoxifying chemicals. These enzymes of phase II reactions act on oxygenated intermediates (phase I products) by conjugation with various endogenous compounds (like glucuronide, glutathione and sulphate) to produce hydrophilic products easily excreted from the body. The best studied group is the glutathione S-transferases (GST) which can detoxify phase I products by conjugation with glutathione. Glutathione S-transferases play a major role in detoxification of electrophilic chemicals and their metabolites. These enzymes have an important protective role in chemical carcinogenesis. Several carcinogens, such as the reactive benzo[a]pyrene diol-epoxide (i.e., tobacco smoke), aflatoxin-2,3-epoxide, sulphates, and many environmental pollutants are good substrates ${ }^{23}$.

In humans, 10 cytosolic GST's are known which are classified into 5 families $(\square, \square, \square, \square, \square)$. For the isoenzymes GST $\square 1$ and $G S T \square 1$ the functional variability is almost completely explained and correctly predicted by genotype. These polymor- 
phisms are also associated with complete functional deficiency which are of prime interest in chemical carcinogenesis. GST 1 efficiently detoxifies PAHs, and a number of other chemicals. Roughly half of all whites entirely lack the gene for GST $1^{38}$.

\section{NAT}

The acetylation by $\mathrm{N}$-acetyltransferase, which is an important activation/inactivation reaction of many chemicals in humans, is encoded by two distinct genes, NAT1 and NAT2. The NAT enzymes catalyse the acetylation of a wide variety of amines, among which are both arylamines and heterocyclic aromatic amines ${ }^{4}$. The NAT enzymes are able to perform both bioactivation and bioinactivation reactions. Several allelic variants of both genes have been detected, some which may have a significant effect on individual susceptibility to aromatic amine-induced cancers.

Epidemiological studies have shown that fast acetylators (NAT2) are at larger risk for colon cancer when compared with slow acetylators. In contrast, fast acetylators (NAT2) are at lower risk for bladder cancer when compared with slow acetylators. Rapid acetylators carrying a certain genotype of $N A T 2$ have been linked to an increased risk of lung cancer. This variability may be due to the different metabolism of arylamines and heterocyclic amines in slow and fast acetylators ${ }^{22,38}$.

\section{$m E H$}

Microsomal epoxide hydrolase ( $m E H$ or $E P H X$ ) metabolises a large number of alkene and arene epoxides to dihydrodiols. The conversion of reactive epoxides is often a bioinactivation reaction. However, in some cases $m E H$ may be involved in a bioactivation, such as the formation of 7,8-dihydrodiol-9,10-epoxide from benzo[a]pyrene. These enzymes play an important role in the detoxification of potentially toxic or carcinogenic epoxides. Two genetic polymorphisms have been detected which are suspected to have an effect on the metabolism and toxicity of chemicals. Especially, this may be the case in combination with genetic polymorphisms of other biotransformation enzymes ${ }^{22-24,39,40}$.

\section{REFERENCES}

1. Venitt S. Mechanisms of carcinogenesis and individual susceptibility to cancer. Clin Chem 1994; 42: 14211425.

2. Elledge SJ. Cell cycle checkpoints: preventing an identity crisis. Science 1996; 274: 1664-1672.

3. Vogel F, Motulsky G. Human genetics. 3rd edn. Berlin: Springer-Verlag, 1997.

4. d'Errico A, Taioli E, Chen X, Vineis P. Genetic metabolic polymorphisms and the risk of cancer: a review of the literature. Biomarkers 1996; 1: 149-173.

5. Forni A. Benzene-induced chromosome-aberrations: A follow-up study. Environ Health Perspect 1996; 104: $1309-1312$.

6. Hemminki K, Dipple A, Shuker DEG, Kadlubar FF, Segerback D, Bartsch H. DNA adducts, identification and biological significance. Lyon: IARC Scientific Publications, 1994.

7. Jelmert $\varnothing$, Hansteen I-L, Langård S. Enhanced cytogenetic detection of previous in vivo exposure to mutagens in human lymphocytes after treatment with inhibitors of DNA synthesis and DNA repair in vitro. Mut Res 1992; 271: 289-298.

8. Kure EH, Andreassen Å, Øvrebø S, Grzybowska E, Fiala Z, Strozyk M, et al. Benzo(a)pyrene-albumin adducts in humans exposed to polycyclic aromatic hydrocarbons in an industrial area of Poland. Occup Environ Med 1997; 54: 662-666.

9. Ollikainen T, Hirvonen A, Norrpa H. Influence of GSTT1 genotype on sister chromatid exchange induction by styrene-7,8-oxide in cultured human lymphocytes. Environ Mol Mutagen 1998; 31: 311-315.

10. Xu X, Wiencke JK, Niu T, Wang M, Watanabe H, Kelsey KT, et al. Benzene exposure, Glutathione Stransferase theta homozygous deletion, and sister chromatid exchange. Am J Ind Med 1998; 33: 157-163.

11. Nordic study group on the health risk of chromosome damage. A Nordic data base on somatic chromosome damage in humans. Mut Res 1990; 241: 325-337.

12. The Nordic study group on the health risk of chromosome damage, Brøgger A, Hagmar L, Hansteen I-L, Heim S, Högstedt B, et al. An inter-Nordic prospective study on cytogenetic endpoints and cancer risk. Cancer Genet Cytogenet 1990; 45: 85-92.

13. Hagmar L, Bonassi S, Strömberg U, Mikoczy Z, Lando C, Hansteen I-L, et al. Cancer predictive value of cytogenetic markers used in occupational health surveillance programs: a report from an ongoing study by the European Study Group on Cytogenetic Biomarkers and Health. Mut Res 1998; 405: 171-178.

14. Yang Q, Khoury MJ. Evolving methods in genetic epidemiology. III. Gene-environment interaction in epidemiologic research. Epidemiol Rev 1997; 19: 33-43.

15. Hansteen I-L, Kure EH, Wanders SP. Undersøkelse av mulige arvestoffskader etter eksponering ved vedlikeholdsavdelingen, etylenfabrikken, Hydro Rafnes. 1999; Rapport 99.01.

16. Skyberg K, Hansteen I-L, Jelmert Ø, Rønneberg A. A cytogenetic and haematological investigation of oil exposed workers in a Norwegian cable manufacturing company. Br J Ind Med 1989; 46: 791-798. 
17. Barch MJ, Knutsen T, Spurbech JL. The AGT cytogenetic laboratory manual. 3rd edn. New York: Lippincott-Raven publishers, 1997.

18. Sambrook J, Fritsch EF, Maniatis T. Molecular cloning. A laboratory manual. 2nd edn. USA: Cold Spring Laboratory Press, 1989.

19. Nedelcheva V, Persson I, Ingelman-Sundberg M. Genetic polymorphism of human cytochrome P450 2 E1. Methods Enzymol 1996; 272: 218-225.

20. Kristensen V, Ikdahl Andersen T, Erikstein B, Geitvik G, Skovlund E, Nesland JM, et al. Single tube multiplex polymerase chain reaction genotype analysis of GSTM1, GSTT1 and GSTP1: relation of genotypes to TP53 tumor status and clinicopathological variables in breast cancer patients. Pharmacogenetics 1998; 8: 1-7.

21. Cascorbi I, Brockmöller J, Roots I. A C4487A polymorphism in exon 7 of human CYP1A1: Population frequency, mutation linkages, and impact on lung cancer susceptibility. Cancer Res 1996; 56: 4965-4969.

22. Brockmöller J, Cascorbi I, Kerb R, Roots I. Combined analysis of inherited polymorphisms in arylamine Nacetyltransferase 2, glutathione S-transferases M1 and T1, microsomal epoxide hydrolase, and cytochrome P450 enzynes as modulators of bladder cancer risk. Cancer Res 1996; 56: 3915-3925.

23. Seidegård J, Ekström G. The role of human glutathione transferases and epoxide hydrolases in the metabolism of xenobiotics. Environ Health Perspect 1997; 105: 791-799.

24. Hassett C, Aicher L, Sidhu JS, Omiecinski CJ. Human microsomal epoxide hydrolase: genetic polymorphism and functional expression in vitro of amino acid variants. Hum Mol Genet 1994; 3: 421-428.

25. Srám RJ. Effect of glutathione S-transferase M1 polymorphisms on biomarkers of exposure and effect. Environ Health Perspect 1998; 106: 231-239.

26. Mrozikiewicz PM, Cascorbi I, Brockmöller J, Roots I. CYP1A1 mutations 4887A, 4889G, 5639C and 6235C in the Polish population and their allelic linkage, determined by peptide nucleic acid-mediated PCR clamping. Pharmacogenetics 1997; 7: 303-307.

27. Ryberg D, Skaug V, Hewer A, Phillips DH, Harries LW, Wolf CR, et al. Genotypes of glutathione transferase $\mathrm{M} 1$ and P1 and their significance for lung DNA adduct level and cancer risk. Carcinogenesis 1997; 18: $1285-$ 1289.

28. Tomanin R, Ballarin C, Bartolucci GB, De Rosa E, Sessa G, Iannini G, et al. Chromosome aberrations and micronuclei in lymphocytes of workers exposed to low and medium levels of styrene. Int Arch Occup Environ Health 1992; 64: 209-215.

29. Wong R-H, Wang J-D, Hsieh L-L, Du C-L, Cheng T-J. Effects of sister chromatid exchange frequency of aldehyde dehydrogenase 2 genotype and smoking in vinyl chloride workers. Mut Res 1998; 420: 99-107.

30. Scarpato R, Hirvonen A, Migliore L, Falck G, Norrpa H. Influence of GSTM1 and GSTT1 polymorphisms on the frequency of chromosome aberrations in lymphocytes of smokers and pesticide-exposed greenhouse workers. Mut Res 1997; 389: 227-235.

31. Norrpa H. Cytogenetic markers of susceptibility: Influence of polymorphic carcinogenmetabolizing enzymes. Environ Health Perspect 1997; 105: 829-835.

32. Landi S, Norrpa H, Frenzilli G, Cipollini G, Ponzanelli I, Barale R, et al. Individual sensitivity to cytogenetic effects of 1,2:3,4-diepoxybutane in cultured human lymphocytes: influence of glutathione S-transferase M1, P1 and T1 genotypes. Pharmacogenetics 1998; 8: 461-471.

33. Hirvonen A, Polymorphisms of xenobiotic-metabolizing enzymes and susceptibility to cancer. Environ Health Perspect 1999; 107: 37-47.

34. Guengerich FP, Shimada T. Activation of procarcinogens by human cytochrome P450 enzymes. Mut Res 1998; 400: 201-213.

35. Hong JY, Yang CS. Genetic polymorphism of cytochrome P450 as a biomarker of susceptibility to environmental toxiciy. Environ Health Perspect 1997; 105: 759-762.

36. Lewis DFV, Watson E, Lake BG. Evolution of the cytochrome P450 superfamily: sequence alignments and pharmacogenetics. Mut Res 1998; 410: 245-270.

37. Nedelcheva V, Gut I. P450 in the rat and man: methods of investigation, substrate specificities and relevance to cancer. Xenobiotica 1994; 24: 1151-1175.

38. Wormhoudt LW, Commandeur JNM, Vermeulen NPE. Genetic polymorphisms of human N-acetyltransferase, cytochrome P450, glutathione-S-transferase, and epoxide hydrolase enzymes: relevance to xenobiotic metabolism and toxicity. Crit Rev Toxicol 1999; 29: 59-124.

39. Benhamou S, Reinikainen M, Bouchardy C, Dayer P, Hirvonen A. Association between lung cancer and microsomal epoxide hydrolase genotypes. Cancer Res 1998; 58: 5291-5293.

40. Hassett C, Robinson KB, Beck NB, Omiecinski CJ. The human microsomal epoxide hydrolase gene (EPHX1): Complete nucleotide sequence and structural characterization. Genomics 1994; 23: 433-442. 